\title{
History Curriculum Policy for Highschool In New Order Era
}

\author{
Zulkarnain \\ Universitas Negeri Yogyakarta \\ Yogyakarta, Indonesia \\ zulkarnain@uny.ac.id
}

\begin{abstract}
This study aims to finds out: the policy of history curriculum for High school during the New Order era. The research method used is qualitative research using a historical approach. This study uses document studies as the main method. The document study was carried out on primary and secondary source for the purpose of source triangulation. In addition to document studies, this study also uses the interview method as a complementary method. Interviews were conducted with several education practitioners and academics including of the Indonesian history curriculum. Data analysis used was interactive analysis models. In the New Order period there was a change in curriculum policy, namely by implementing the 1968 curriculum. This curriculum is also inseparable from the political content of the New Order to eliminate the image of old order government that symbolized by President Sukarno, better known as the NASAKOM doctrine. The philosophical basis for the implementation of curriculum policy for Indonesian history lesson in high school during the New Order are based on Pancasila and the 1945 Constitution, although in its implementation the philosophy of education is more directed to the government's politic and philosophical school of essentialism and perennialism; (3) the position of history lesson in high school in the New Order era are very strategic in fostering the spirit of the young generation to be able to understand and applying the Pancasila and UUD 1945 value purely and consistently in the nation and state life, implantation of nationality value is carried out through the process of learning in school namely through the perfection process from time to time, however, in the process of its implementation there was a shift in which the learning of history was influenced more by the New Order's political power policy which was more directed at Suhartoism and anti-Sukarno narratives where students were strongly indicated to be instruments of development.
\end{abstract}

Keywords: educational policy, history curriculum in new order era, high school

\section{INTRODUCTION}

Indonesian history lesson curriculum has a strategic meaning in the formation of dignified national character and civilization and in the formation of Indonesian people who have a sense of nationality and love of the homeland. History learning has general goals which include: developing an understanding about oneself; provide a precise picture of the concept of space, time and society; make people able to evaluate the values and results achieved by their generation; teach tolerance; instill intellectual attitude; expand intellectual horizons; teach moral principles; instill orientation into the future; provide mental training; train students to handle controversial issues; help find solutions for various social and individual problems; strengthen nationalism; develop international understanding; and develop useful skills [1].

The main problem that has so far shackled the Indonesian history curriculum is the politicization of historical education, namely policy changes in the education world along with changes in leadership in Indonesia. This has an impact on the success of student learning in the field of Indonesian history lessons. Broadly speaking, there are two variables that can affect the success of student learning, namely the availability and support of input and the quality of learning. The input consists of students, teachers, curriculum, and learning facilities and infrastructure. Quality of learning is a measure that shows how high the quality of interaction between teachers and students in the learning process in order to achieve certain goals. The teaching and learning activities are carried out in a certain atmosphere with certain curriculum support and learning variables. Therefore, the success of the learning process is very dependent on the teacher, students, curriculum, learning facilities, classroom environment, and class culture. All these indicators must support each other in a quality learning activity system.

The transition of President Sukarno's power to Suharto between 1965-1968 greatly influenced the fundamental changes to the narrative of history lessons, the scope and material for teaching Indonesian history through changes in curriculum policy, namely by applying the 1968 curriculum. There is a mutually influential relationship between politics and curriculum or in simple language the historical curriculum on this era is inseparable from political content, even though the curriculum has been directed towards strengthening religious beliefs. The arrest and murder of seven Revolutionary Heroes by G30S forces led by Lieutenant Colonel Untung on 1 October 1965 was the event that initiated the transfer of power. In the History curriculum in this era there was a narrative victory through the standardization carried out by the authorities which placed the legitimacy of the New Order power as priority competence and placed the New Order as a savior of the Indonesian people from communism who wanted to change the state's ideology, Pancasila. 


\section{DISCUSSION}

Indonesian history lesson curriculum has a strategic meaning in the formation of dignified national character and civilization and in the formation of Indonesian people who have a sense of nationality and love of the homeland. Because, history learning has general goals which include: developing an understanding about oneself; provide a precise picture of the concept of space, time and society; make people able to evaluate the values and results achieved by their generation; teach tolerance; instill intellectual attitude; expand intellectual horizons; teach moral principles; instill orientation into the future; provide mental training; train students to handle controversial issues; help find solutions for various social and individual problems; strengthen nationalism; develop international understanding; and develop useful skills[1].

Study of curriculum and history lesson material if viewed from the historical and philosophical aspects according to Djoko Suryo, preferably based on several study areas, namely: 1) the history of religious thought and philosophy as an explanatory source of changes and the continuity of living beings; 2) the history of civilization and culture as a source of understanding the value and meaning of the continuity and change of human life in dialogue with the surrounding natural environment and its time; 3) national history and local history or macro and micro history of Indonesia is an important foundation for the process of revitalization and reconstruction of the present and future national and state communities; 4) social history or history of society or history from bellows centered on certain groups, community organizations, and small people will complete the picture of the dynamics and development process of Indonesian society broadly, completely and continuously; and 5) Indonesia's constitutional history provides a basis for understanding democracy and the formation of civil society [2].

The transition of President Sukarno's power to Suharto between 1965-1968 greatly influenced the fundamental changes to the narrative of history lessons, the scope and material for teaching Indonesian history through changes in curriculum policy, namely by applying the 1968 curriculum. There is a mutually influential relationship between politics and curriculum or in simple language the historical curriculum on this era is inseparable from political content, even though the curriculum has been directed towards strengthening religious beliefs. The arrest and murder of seven Revolutionary Heroes by G30S forces led by Lieutenant Colonel Untung on 1 October 1965 was the event that initiated the transfer of power. In the History curriculum in this era there was a narrative victory through the standardization carried out by the authorities which placed the legitimacy of the New Order power as priority competence and placed the New Order as a savior of the Indonesian people from communism who wanted to change the state's ideology, Pancasila.

In 1975 curriculum changes occur or better known as the 1975 Indonesian history curriculum, historical education material in this curriculum is more inspired by the Pancasila morality, and emphasize the importance of 1945 values for the next generation [3]. This New Order-based curriculum also only lasted nine years and was later replaced with the 1984 curriculum. In the 1984 curriculum, it was emphasized that the education sector must support national development in all fields. To support that, students as human beings of development must have nation hood or nationalism; have personality and national integrity, as well as forming a comprehensive character building or better known as the PSPB curriculum. After being criticized by a lot of parties finally the government, historians and education experts removed the subjects of PSPB rather than rearranging the scope and teaching materials of Indonesia. This change was made through the Decree No.061/U/1993 nomenclature about the General Middle Curriculum. This nomenclature is better known as the 1994 curriculum.

The new order was born with the hope that there would be new changes in all national and state life in accordance with the philosophy of Pancasila and the 1945 Constitution. In the constitution of the state, precisely in the opening of the fourth paragraph of the 1945 Constitution, it clearly places education as one of the main priorities in the nation and state life. Theoretically, of course this is very pleasant, but the reality in the field, the strategic role of education, especially the history of Indonesia is more widely used as a mere political tool in order to preserve its power for 32 years. The focus of the development of the New Order government which had been in power for 32 years focused more on political and economic strengthening. One of the reasons the author dares to say that education in the New Order era was only used as a means of political indoctrination is the existence of Pancasila and P4 (Pedoman Penghayatan dan Pengamalan Pancasila) as well as history lessons in schools, schools talk more about figure personhood, the greatness of historical actors who coincidentally in power.

The New Order government tried hard to improve its image by making changes in various aspects of life. Improvements began in the fields of politics, economics, defense, security and education. Changes in education are characterized by changes in the education curriculum in Indonesia. In the 1968 Curriculum, Indonesia's historical material position was included in the Citizenship Education curriculum material. The scope and content of the teaching of Indonesian history is the most important part because it involves strengthening the legitimacy of the New Order's power which has taken the power from President Sukarno to President Suharto through gradual, planned and systematic power transition. The emergence of the 
curriculum for history lessons in 1968 was more political, replacing the 1964 education plan which was imaged as a product of the Old Order. The following will briefly explain the development of the history curriculum in high school:

\section{The 1968 History Curriculum}

The 1968 curriculum became a national program and must be taught in schools including in high school. The teaching is uniformed in all schools. This resulted in the curriculum and material of Indonesian history in high school being standardized. In general, the 1968 curriculum contains material on anti-communism, antiSukarno, anti-Liberal Democracy, and anti-Guided Democracy. In addition to the curriculum material that very against the Old Order, the curriculum material and books published in the SNI standard were very pro and even worshiped Suharto's struggle to maintain independence and save the Indonesian people from internal conflicts that led to national disintegration and social disintegration. The material is very pro to Pancasila, pro-ruler and New Order programs. Because of the 1968 curriculum, the author increasingly believes that Indonesia's historical curriculum from time to time is compiled and designed in the context of indoctrination and legitimization of power. Indonesia's history curriculum has never been separated from the influence of state ideology and power. The 1968 curriculum ran for approximately six years, but there were still many weaknesses so that the government reimplemented the new curriculum known as the national education curriculum in 1975 .

\section{The 1975 Curriculum}

The emergence of the 1975 Curriculum was due to the rapid pace and success of the New Order government. Therefore, these successes need to be taught to students through curriculum changes. The change occurred since 1969, such as: Pelita I gave birth to new ideas about the implementation of the national education system, the 1973 GBHN which regulates education, the results of analysis and assessment of national education by the Ministry of Education and Culture, the existence of innovations in teaching and learning systems, and complaints community about the quality of education graduates. In addition, the 1968 curriculum was not in accordance with the demands of the community $[4,8]$.

The 1975 curriculum is the first curriculum in Indonesia which is developed based on processes and procedures based on curriculum development theory. Even so, the 1975 curriculum was still developed based on the thought of the dominant philosophical orientation of scientific education and not oriented to development. This does not mean that the 1975 curriculum has released itself from political influence. This is not something strange and specific in Indonesia, because anywhere in the world, the curriculum cannot escape from political influence $[9,10,11]$.
The principle of implementing the 1975 curriculum includes: goal-oriented, adopting an integrative approach and flexibility, emphasizing effectiveness and efficiency, adhering to the PPSI (Instructional System Development Procedures) system approach, and influenced by environmental psychology. The new approach used in the 1975 curriculum development is the learning process that uses an active student learning approach (CBSA), the PPSI (instructional system development procedures) approach, and the application of objective items for assessment of learning outcomes $[4,5,8,12]$.

The notion in the CBSA model is that participants must actively seek, find, and communicate their learning outcomes, while the teacher is tasked with providing facilities to learn. Unfortunately, the curriculum model and definition of curriculum content used are not adjusted to this approach. The curriculum model that is oriented to the process curriculum model that requires reinforcement is not used; the curriculum model used is "content-based curriculum". The definition of curriculum content is also limited to substantive content so that the process is not developed and taught as content [13]. In its implementation, the 1975 curriculum book is supplemented with concrete examples of how to prepare the teaching process in the "unit learning model" class. The framework of this unit learning model includes fields of study, subjects/subfields of study, subject matter, class, semester, and time [4].

Thus the special characteristic of the 1975 curriculum is to adopt a goal-oriented approach that requires every teacher to be competent, adopt an integrative approach, emphasize to students to have a moral that is in accordance with Pancasila so that Pancasila moral coaching is also imposed on social studies, especially history, which has a lot of moral values in every event and exemplary hero character, emphasizing the efficiency and effectiveness of the use of funds, power, and time $[4,5]$. The characteristic of the 1975 high school curriculum is goal-oriented with an integrated curriculum organization with several allied subjects. The principles underlying the 1975 curriculum are 1) the principle of flexibility in programs measured by ecosystems (environment), the ability of the government and the community and guardians of students in providing facilities; 2) the principle of efficiency and effectiveness influence the number of hours of study that are reduced from the previous curriculum (42 hours to 36 hours a week), each subject is given at least 2 hours instead of 1 hour, and the preparation of the lesson schedule every week; 3 ) the principle of being goal oriented influences every hour and the learning activities are really directed towards achieving the educational goals; 5) the principle of lifelong education means that school is not the only place to study [4].

Educational programs in the 1975 curriculum include: General Education Programs, Academic 
Education, and Skills Education. Majors are divided into Natural Sciences (IPA), Social Sciences (IPS), and Linguistics. Selection of student majors is conducted in the second semester of grade I. For grade I and II the number of class hours is 37 hours per week ( 9 subjects in grade I and 13 subjects in grade II), while grade III is 36 hours per week with 10 subjects $[5,14]$.

History lesson are only given to social studies programs in grade I and II and linguistic programs in grade III. In grade I history subjects are given in semester 2 with 4 hours per week. In grade II history subjects are given for two semesters with 3 hours per week, while for grade 3 the subjects are eliminated. In the linguistic program, history lessons are given in grade 3 for two semesters with 7 class hours per week [5].

To implement the objectives of the 1975 curriculum which emphasize that high school graduates are truly qualified so that in the ability curriculum (intelligence and skills), knowledge and attitudes are formulated in forms of educational goals which are divided into several levels, the history subjects also have curricular objectives (the purpose for which the achievement is charged to the program of a subject area); and instructional goals (goals which reach the teaching program unit of a subject area) [4].

Based on the curricular objectives and instructional objectives of the historical lesson in 1975, history has the potential to realize the goals of national education, especially shape the character of students, without ignoring historical knowledge. Therefore, the role of the teacher is needed in directing students in understanding each lesson from every historical event, especially national history. And, historical lesson material taught in the 1975 curriculum.

Likewise, for history subjects, the learning tool has used the unit learning model. In the composition of the unit learning model for subjects consisting of the title, field of study, course, subjects, class, semester, time, general instructions (methods, things that need to be repeated in units of learning, starting points of the presentation of lesson units), instructional objectives (general and specific instructional goals), subject matter, teaching and learning activities (teacher and student activities), group assignments, learning tools (sources, tools / materials consisting of student and teacher tools), and evaluation. Therefore, this curriculum requires teachers to be more detailed in making reports, without putting aside the material presented to students so that the teacher must also master the subject matter. In addition, the students' ability can be seen from the evaluation conducted by the teacher, both through pre-test and post-test. Pre-test requires the readiness of students in learning, while the post-test provides an overview of the development of students' understanding of the material presented.

The assignments given by the teacher also train students to be smart, creative and active, because most of the tasks are portfolio type so the activeness of students becomes very decisive. So, this curriculum is potential in educating students to have characters who are ready to face global challenges.

\section{The 1984 Curriculum}

High school curriculum structure in 1984 experiencing fundamental changes compared to the previous high school curriculum, in the 1984 high school curriculum the subjects are grouped into two, namely the core program (compulsory for all students) and special programs (electives). However, the implementation of B program has been delayed. Doing $\mathrm{A}$ and $\mathrm{B}$ programs can be done in the semester for graduates who work after graduating from high school if they succeed in developing academic skills to continue their education after 2 or 3 years, there are still open opportunities to continue their education in tertiary institutions, provided they meet the requirements needed by the college concerned [6]. The implementation of the 1984 curriculum in high school took place in phases: the first phase of the 1984/1985 school year began in grade 1 , the second phase of the 1985/1986 school year began in grade 1 and II, the third stage of the entire 1986/1987 academic year [14]

From the document review conducted by researchers the purpose of the National History Education subject is to instill in students the values of willingness to sacrifice, unity, cooperation, mutual respect, and pride as a nation and homeland of Indonesia. The National History Education subject is a core subject that must be attended by students. The number of class hours for grade 1 is 36 class hours, grade II is 34 class hours, and grade III is 34 class hours $[6,7]$.

Based on the analysis and review of the document carried out by researchers it appears that the national history lesson is indeed strategically developed for students to become young generation who have the spirit of nationality and love of the homeland, especially today the young generation that has forgotten a lot of their Indonesian identity. However, the time for classes in grade II and III was reduced by two hours, even though these subjects had the potential to shape the character of the young generation through exemplary characters and lessons from events. This is in line with the appeal of the minister of education and culture that the approach used in the teaching and learning process uses values education and students' active roles. The government also targets the education curriculum of the nation's history to be useful and effective. So efforts were made to develop and procure learning facilities and resources, including writing textbooks and reading books for students, handbooks and teacher manuals, as well as historical plays, historical films, heroic songs, museums, wall pictures, historical sites, historical photos, and historical monuments, so as to foster the spirit of struggle and national unity [6]. Therefore, these subjects are 
synergistic with historical subjects so that in teaching and learning activities there needs to be coordination in order to avoid overlapping material.

History lesson in the 1984 curriculum are called Indonesia's national history and world history. These subjects are given to all programs and are included in the core lesson with the same amount of learning load that is 14 credits. History is given thoroughly from semester 1 to semester 6 . Grade 1 is given 4 hours per week, grade II and III are given 2 hours per week [5, 6]. Grade 1 to grade III lesson material is the same as the 1975 curriculum. However, there are additional new elements that must be integrated with the appropriate material subjects such as political education and archipelago insight.

Based on the document analysis, it can be concluded that the 1984 curriculum on historical subjects emphasizes concept understanding so that students have the ability towards the core of the material that facilitates students in linking between one event and another, and the students to have usefulness. In addition, there are additional new elements that are in accordance with the material. The order of material in the 1984 curriculum is also more chronological.

\section{The 1994 Curriculum}

This 1994 curriculum is a revision of the 1984 curriculum which perceived that the content of material contained in the subject matter was too solid so that the lack of material provided to students was less profound. Besides that, there are overlaps in historical subjects with the education of national history. The basis for the implementation of the 1994 curriculum is by Law No. 2 of 1989 about the National Education System. The basis for setting the 1994 curriculum was the Minister of Education and Culture Decree No.061/U/ 93 dated February 25, 1993 and PP No.29/1990 about Secondary Education. Based on Law Number 2 of 1989, the name of the SMA changed to SMU.

The implementation of the 1994 curriculum was carried out in stages; in the grade I it began in the $1994 / 1995$ school year, grade II and III began in the 1995/1996 school year, so that the 1994 curriculum could be implemented in all classes of the 1996/1997 school year. In addition, there are also new traits in the 1994 curriculum which include: 1) lithe and flexible, 2) high schools' students are prepared to go to college; and 3) curriculum for vocational education added more hours for practice and internships in industry [5]. If in the 1984 curriculum in grade II, the 1994 curriculum majoring is done in grade III. Learning hours for general programs have increased compared to the previous curriculum, from 37 to 42 . The 1994 curriculum also includes curricular programs and extracurricular programs held outside school hours [15].

History lessons have also changed to National History and General History (in the 1984 curriculum called Indonesian History and World History). Likewise, in class hours for grade I it was reduced by one hour from the initial 3 hours per week in the 1994 curriculum to 2 hours per week. Even though history subjects are still given in the curriculum of high school science majors with 2 hours per week. In the 1994 curriculum the media serves as a means of delivering information/attracting students' attention. In terms of evaluation, in the 1994 curriculum assessment was carried out to achieve national standards, the assessment criteria were not differentiated so that it did not touch the aspects of student personality.

The 1994 curriculum provides space for history subjects to foster a sense of pride and love for the homeland, so that the material is focused on the life journey of the people in the past to the present, national and world. There are nine scopes in the national history and general history material which are divided into three classes. National history and general history lessons for grade 1 quarter 1 for 24 class hours, 2nd quarter for 24 class hours, 3rd quarter for 20 class hours; grade II quarter 1 for 24 class hours of study, quarter 2 for 24 class hours, quarter 3 for 20 class hours; and grade III quarter 1 for 24 class hours, quarter 2 for 24 class hours, quarter 3 for 16 class hours [5]. These national history and general history subjects serve to understand knowledge about history so that it can develop national identity and insight between nations. The following are the teaching objectives of the National History and General History Course for Grade I, II and II in 1994 curriculum.

Based on the analysis and review of the curriculum document conducted by researchers, it can be explained that national history and general history subjects are very strategic in equipping young people with Indonesian characteristics through the values behind every historical event obtained in high school. To achieve this goal, there are subject matter and subsubject matter in the subject matter of national history and general history. And lessons on national history and general history in the 1994 curriculum. National history and general history materials in the 1994 curriculum refine the previous curriculum in which the subject matter is so profound and does not only discuss the surface, so the history teacher must master the material. Material content are not a lot, so it does not become a burden on the students. In addition, the ability of students to understand deep or even detailed material can be optimized. Therefore, the goal of the 1994 curriculum that prepares high school graduates to continue to higher levels of education is easily realized because graduates have been prepared in a mature mindset.

The 1994 Indonesian History Curriculum is familiar as the product of New Order curriculum, this curriculum has received a lot of criticism from various backgrounds ranging from historical observers, scientists and community leaders and NGOs (nonGovernment Organization) because the curriculum that 
is then represented in the form of historical textbooks, considered to be loaded with the political content of the government so that a lot of historical books are far from the historical facts that exist [2]. The material considered controversy in the 1994 curriculum and widely criticized by various parties was the issue of the September 30, 1965 Movement which was always identified with the PKI as the main character in the event. Even though based on the latest facts found that the incident was not only carried out by the PKI, but there were many masterminds involved in the incident. However, these new facts were silenced if Suharto came to power, even though this material must be included in the Indonesian history curriculum, it should be able to be delivered in a balanced manner.

The 1994 curriculum was created by experts by involving various groups including involving scientists, academics and historical education practitioners, but the situation that was not conducive made the team powerless, because the authoritarian New Order situation caused much of its historical writing away from actual historical facts so it seems the material is manipulated.

\section{CONCLUSIONS}

The position of History Lesson in High School in New Order era is very strategic in fostering the spirit of the young generation to be able to understand and apply the values of Pancasila and the 1945 Constitution purely and consistently in national and state life, the implantation of national values carried out through the process of learning in schools namely through the perfection process from time to time, however in the process of its implementation there was a shift in which the history learning was more influenced by the New Order's political power policies more directed to Suharto's narratives and anti-Sukarno where students were strongly indicated to be instruments of development.

\section{REFERENCES}

[1] Kochhar, S. K. "Pembelajaran Sejarah" Jakarta: PT Gramedia 2008, pp. 27-37.

[2] Djoko Suryo"Paradigma sejarah di Indonesia dan kurikulum sejarah" Surakarta: PPS UNS, 2005, pp. 2.

[3] Asvi Warman Adam "History, Nationalism and Power" Jakarta: Social science and power in Indonesia, 2005, pp. 247 274.

[4] Departemen Pendidikan Nasional, Peraturan Menteri Pendidikan Nasional Republik Indonesia tahun 1975, Jakarta: Depdiknas, pp. 11

[5] Departemen Pendidikan Nasional, Peraturan Menteri Pendidikan Nasional Republik Indonesia tahun 1995, Jakarta: Depdiknas, pp. 250, 345, 500- 502.

[6] Departemen Pendidikan Nasional, Peraturan Menteri Pendidikan Nasional Republik Indonesia tahun 1984, Jakarta: Depdiknas, pp. 11-27.

[7] Departemen Pendidikan Nasional, Peraturan Menteri Pendidikan Nasional Republik Indonesia tahun 1985, Jakarta: Depdiknas, pp. 5-11.
[8] Sholeh Hidayat "Pengembangan Kurikulum Baru" Bandung: PT Remaja Rosdakarya, 2013, pp. 5-7.

[9] Apple, M.W.'Ideology and Curriculum" London: Routledge and Kegan Paul, 1979.

[10] Li, Lanqing "Education for 1.3 Billion: on 10 Years of Education Reform and Development" Beijing: Foreign Language Teaching and Research Press, 2004.

[11] Longstreet, W.S. dan Shane, H.G. "Curriculum for a New Milennium" Boston: Allyn and Bacon, 1993.

[12] Abdullah Idi "Pengembangan Kurikulum, Teori \& Praktik" Jakarta: Rajawali Pers, 2014, pp. 18

[13] Hamalik, Oemar "Proses Belajar Mengajar" Jakarta: Bumi Aksara, 2001, pp. 16-25.

[14] Leo Agung "Telaah kurikulum sekolah menengah di indonesia sejak kemerdekaan hingga reformasi” Yogyakarta: Ombak, 2015, pp. 42.

[15] Departemen Pendidikan Nasional, Peraturan Menteri Pendidikan Nasional Republik Indonesia tahun 1996, Jakarta: Depdiknas, pp. 270-271. 